\title{
Barriers to diagnosis and management of CNS infections in Indonesia
}

Darma Imran, MD, Sekar Satiti, MD, PhD, Paulus Sugianto, MD, PhD, Riwanti Estiasari, MD, PhD, Kartika Maharani, MD, David Pangeran, MD, Putri Widya Andini, MD, MSc, Badrul Munir, MD, Arthur H.P. Mawuntu, MD, Ni Made Susilawathi, MD, PhD, Kiking Ritarwan, MD, PhD, O.S. Hartanto, MD, PhD, Meity Frida, MD, Ahmad Rizal Ganiem, MD, PhD, Dede Gunawan, MD, Sofiati Dian, MD, MSc, A.A.R. Sudewi, MD, PhD, and Reinout van Crevel, MD, PhD

Neurology ${ }^{\circledR}$ 2019;92:104-106. doi:10.1212/WNL.0000000000006732

Little is known about the management and outcome of CNS infections in Indonesia (population: approximately 261 million), and the burden of CNS infections is increasing as result of a rapidly growing HIV epidemic. Indeed, in a recent study in Jakarta, ${ }^{1} 54 \%$ of patients with a CNS infection were HIV-infected, vs $25 \%$ in a similar study conducted in Bandung, the second largest city on Java. ${ }^{2}$ Establishing the etiology of CNS infections is important for clinical management and outcome, but anecdotal evidence suggests that there are major gaps in clinical management, including a failure to recognize CNS infections, perform appropriate diagnostics, or initiate necessary drug treatment. In this study, we address some of these barriers by interviewing a group of Indonesian neurologists.

On behalf of the Indonesian Neurologic Association, neurologists who attend the National Neurology Conference (July 27-30, 2017, Yogyakarta) were given questionnaires to complete with respect to the frequency and type of CNS infections and possible barriers in diagnosis and treatment. The questionnaire was developed and piloted in Cipto Mangunkusumo Hospital, Jakarta, and adjusted with feedback from the neuroinfection working group.

The anonymous paper questionnaire (available as supplementary material, links.lww.com/ WNL/A775) was completed by 288 neurologists (median age 41 years, $56 \%$ female) from tertiary (19\%), regional (48\%), or district (30\%) hospitals in Java/Bali (62\%), Sumatra (22\%), Sulawesi (7\%), Kalimantan (6\%), and the eastern islands including Papua (3.2\%). Most (67\%) had worked fewer than 10 years since their neurology training. Almost all neurologists (93\%) had seen presumptive CNS infections in the last 3 months; however, only $15 \%$ had performed lumbar puncture (LP) during this same period. More recently qualified neurologists and those working in regional hospitals reported a higher number of CNS infections and LPs. ${ }^{1} \mathrm{Neu}-$ rologists' considerations not to perform LP included "unfavorable condition of the patient," logistical issues like lack of LP kits, and concerns regarding possible blame from the family if complications would occur (table). Fear of complications, such as pain, paralysis, and death, was also reported as a reason for patient reluctance to undergo LP. Most neurologists mentioned shock (90\%), raised intracranial pressure (89\%), brain herniation (87\%), and papilledema (86\%) as contraindications for LP, but $35 \%$ also mentioned HIV infection as contraindication for LP. When asked what blood examinations they would like to order in approaching suspected CNS infection cases, only 15 (5\%) spontaneously mentioned HIV testing.

With regard to specific diagnosis and treatment, serious barriers were identified. The majority of neurologists reported working in a hospital where CT scans $(81 \%)$ and routine CSF examination (73\%) are available. However, only a small number mentioned having access to specific microbiological testing for tuberculous meningitis, cryptococcal meningitis, and viral

\author{
Correspondence \\ Dr. Imran \\ darma_imran@yahoo.com
}


Table Experience of Indonesian neurologists $(n=288)$ regarding diagnosis and management of CNS infection

\begin{tabular}{|c|c|}
\hline & Percent \\
\hline \multicolumn{2}{|c|}{ Patients with suspected CNS infections in the last 3 months } \\
\hline 0 & 7 \\
\hline $1-5$ & 60 \\
\hline $6-10$ & 20 \\
\hline$>10$ & 13 \\
\hline \multicolumn{2}{|l|}{ LP performed in the last 3 months } \\
\hline None & 40 \\
\hline $1-3$ & 41 \\
\hline$>3$ & 19 \\
\hline \multicolumn{2}{|l|}{ Reasons for not performing LP } \\
\hline \multicolumn{2}{|l|}{ Patient reluctance for $\mathrm{LP}$} \\
\hline Fear of complication & 78 \\
\hline Financial constraints & 15 \\
\hline \multicolumn{2}{|l|}{ Doctors' concerns regarding LP } \\
\hline Unfavorable condition of the patient & 64 \\
\hline No supporting facilities (LP kit) & 29 \\
\hline LP infrequently performed & 7 \\
\hline $\begin{array}{l}\text { Fear of being blamed by the family in case of } \\
\text { complications }\end{array}$ & 25 \\
\hline
\end{tabular}

\section{Perceived contraindications for LP}

\begin{tabular}{ll}
\hline Increased intracranial pressure & 89 \\
\hline HIV infection & 35 \\
\hline Intracranial mass & 82 \\
\hline Availability of CT scan/MRI & 81 \\
\hline
\end{tabular}

\section{Availability of CSF laboratory tests}

Routine CSF analysis (protein, leukocytes, glucose)

\begin{tabular}{ll}
\hline Tuberculosis diagnostics & 71 \\
\hline Microscopy & 56 \\
\hline GeneXpert MTB/RIF & 26 \\
\hline Solid culture & 34 \\
\hline Microscopy (India ink) for Cryptococcus & 39 \\
\hline PCR for HSV, VZV, or CMV & 20
\end{tabular}

\section{Availability of specific medication for CNS infections}

Tuberculous meningitis (FDC tuberculosis drugs)

Cerebral toxoplasmosis

$$
\text { Pyrimethamine }
$$

Clindamycin
Table Experience of Indonesian neurologists $(n=288)$ regarding diagnosis and management of CNS infection (continued)

Percent

Cryptococcal meningitis

\begin{tabular}{lc}
\hline Fluconazole & 67 \\
\hline Amphotericin B & 43 \\
\hline Viral encephalitis & 91 \\
\hline Acyclovir & 43 \\
\hline Valacyclovir & \\
\hline
\end{tabular}

Abbreviations: $\mathrm{CMV}=$ cytomegalovirus; $\mathrm{FDC}$ = fixed-dose combination; $\mathrm{HSV}=$ herpes simplex virus; $\mathrm{LP}=$ lumbar puncture; VZV = varicella-zoster virus. Paper-based questionnaires were completed during the annual Indonesian Neurology meeting (July $27-30,2017$, Yogyakarta); $98 \%-100 \%$ of questions included in the table were complete.

encephalitis (table). Similarly, many reported a lack of drug treatment for cerebral toxoplasmosis or cryptococcal meningitis (table). In daily practice, the situation might be even more difficult, as supply of certain tests (e.g., Xpert MTB/RIF cartridges) or medication (e.g., amphotericin B) is often interrupted, or costs are not covered by patients' insurance.

Based on our findings, several conclusions can be drawn. First, it seems that neurologists in Indonesia frequently encounter patients with suspected CNS infections, but often fail to do LP. A previous report from Uganda described how educational material helped decrease patient refusal to undergo LP. ${ }^{3}$ Our data suggest that it may be at least as important to improve doctors' knowledge and skills. Experienced groups with an interest in CNS infections in Bandung and Jakarta who have reported high rates of large-volume LPs, with $<5 \%$ refusal rate, might take the lead in educating other neurologists in Indonesia. ${ }^{1,2}$ Second, many neurologists mentioned having no access to appropriate diagnostics and specific microbiological testing, something that could be defined as a health systems constraint. WHO has defined 6 building blocks of a health system (service delivery, health workforce, information, medical products and technologies, financing, and leadership), which were used recently for constraints analysis for neurologic disease in Timor-Leste, a low-income country neighboring Indonesia. ${ }^{4}$ One could apply a similar approach specifically for CNS infections. Our third conclusion is that HIV testing does not seem standard for patients with suspected CNS infection, even though a patient's HIV status is relevant in terms of the etiology and management of CNS infections, and that many neurologists consider HIV infection as a contraindication for doing LP. This is worrying, as in a recent cohort study in Jakarta we found that $54 \%$ of adult patients with CNS infections were HIV-infected, with half of this group diagnosed with HIV infection previously, but only a minority receiving antiretroviral therapy, and with a median CD4 cell count of $30 \mu \mathrm{L}$ both among newly and previously 
diagnosed patients. ${ }^{1}$ These findings and those of the present study underscore the urgent need to address the many barriers to providing good care for patients with suspected or proven CNS infections in Indonesia, as in many low- or middle-income countries. We have reported our findings to the Indonesian Ministry of Health and National Neurology Association. As a next step, based on our findings, we intend to perform a more detailed qualitative and quantitative assessment to prioritize and address amendable gaps in care for patients with CNS infections, as was previously done for management of child contacts of tuberculosis patients in Indonesia. ${ }^{5}$

\section{Author contributions}

Darma Imran: study concept and design, acquisition of data, analysis and interpretation, critical revision of the manuscript for important intellectual content, study supervision. Sekar Satiti: study concept and design, acquisition of data. Paulus Sugianto: study concept and design, acquisition of data. Riwanti Estiasari: study concept and design, critical revision of the manuscript for important intellectual content, study supervision. Kartika Maharani: analysis and interpretation, critical revision of the manuscript for important intellectual content. David Pangeran: acquisition of data, analysis and interpretation, critical revision of the manuscript for important intellectual content. Putri Widya Andini: analysis and interpretation, critical revision of the manuscript for important intellectual content. Badrul Munir: study concept and design, acquisition of data. Arthur H.P. Mawuntu: study concept and design, acquisition of data. Ni Made Susilawati: study concept and design, acquisition of data. Kiking Ritarwan: study concept and design, acquisition of data. O.S. Hartanto: study concept and design, acquisition of data. Meity Frida: study concept and design, acquisition of data. Ahmad
Rizal Ganiem: study concept and design, acquisition of data, critical revision of the manuscript for important intellectual content, study supervision. Dede Gunawan: study concept and design. Sofiati Dian: study concept and design, acquisition of data. A.A.R. Sudewi: study concept and design, acquisition of data, study supervision. Reinout van Crevel: study concept and design, analysis and interpretation, critical revision of the manuscript for important intellectual content, study supervision.

\section{Study funding}

The study was supported by the Indonesian Neurological Association.

\section{Disclosure}

D. Imran received a grant from the Indonesian Neurological Association. S. Satiti, P. Sugianto, R. Estiasari, K. Maharani, D., P. Widya Andini, B. Munir, A. Mawuntu, N. Susilawati, K. Ritarwan, O. Hartanto, M. Frida, A. Rizal Ganiem, D. Gunawan, S. Dian, A. Sudewi, and R. van Crevel report no disclosures relevant to the manuscript. Go to Neurology.org/N for full disclosures.

\section{References}

1. Imran D, Estiasari R, Maharani K, et al. Presentation, etiology and outcome of brain infections in an Indonesian hospital: a cohort study. Neurol Clin Pract Epub 2018 Sep 13.

2. Ganiem AR, Parwati I, Wisaksana R, et al. The effect of HIV infection on adult meningitis in Indonesia: a prospective cohort study. AIDS 2009;23:2309-2316.

3. Thakur KT, Mateyo K, Hachaambwa L, et al. Lumbar puncture refusal in sub-Saharan Africa: a call for further understanding and intervention. Neurology 2015;84: 1988-1990.

4. Mateen FJ, Martins N. A health systems constraints analysis for neurologic diseases: the example of Timor-Leste. Neurology 2014;82:1274-1276.

5. Rutherford ME, Ruslami R, Anselmo M, et al. Management of children exposed to Mycobacterium tuberculosis: a public health evaluation in West Java, Indonesia. Bull World Health Organ 2013;91:932-941A.

\section{Disputes \& Debates: Rapid online correspondence}

The editors encourage comments on recent articles through Disputes \& Debates:

Access an article at Neurology.org/ $\mathrm{N}$ and click on "COMMENT" beneath the article header. Responses will be posted within 3 business days.

Before submitting a comment to Disputes \& Debates, remember the following:

- Disputes \& Debates is restricted to comments about studies published in Neurology within the last eight weeks

- Read previously posted comments; redundant comments will not be posted

- Your submission must be 200 words or less and have a maximum of five references; reference one must be the article on which you are commenting

- You can include a maximum of five authors (including yourself) 


\section{Neurology}

\section{Barriers to diagnosis and management of CNS infections in Indonesia \\ Darma Imran, Sekar Satiti, Paulus Sugianto, et al. \\ Neurology 2019;92;104-106 \\ DOI 10.1212/WNL.0000000000006732}

\section{This information is current as of January 7, 2019}

$\begin{array}{ll}\begin{array}{l}\text { Updated Information \& } \\ \text { Services }\end{array} & \begin{array}{l}\text { including high resolution figures, can be found at: } \\ \text { http://n.neurology.org/content/92/2/104.full }\end{array} \\ \text { References } & \text { This article cites } 4 \text { articles, } 2 \text { of which you can access for free at: } \\ & \text { http://n.neurology.org/content/92/2/104.full\#ref-list-1 } \\ & \text { This article has been cited by } 1 \text { HighWire-hosted articles: } \\ \text { http://n.neurology.org/content/92/2/104.full\#\#otherarticles } & \\ \text { This article, along with others on similar topics, appears in the } & \text { following collection(s): } \\ \text { All global neurology } \\ \text { http://n.neurology.org/cgi/collection/all_global_neurology } \\ \text { Encephalitis } \\ \text { http://n.neurology.org/cgi/collection/encephalitis } \\ \text { HIV } \\ \text { http://n.neurology.org/cgi/collection/hiv } \\ \text { Meningitis } \\ \text { http://n.neurology.org/cgi/collection/meningitis } \\ \text { Information about reproducing this article in parts (figures,tables) or in } \\ \text { its entirety can be found online at: } \\ \text { http://www.neurology.org/about/about_the_journal\#permissions } \\ \text { Information about ordering reprints can be found online: } \\ \text { http://n.neurology.org/subscribers/advertise }\end{array}$

Neurology ${ }^{\circledR}$ is the official journal of the American Academy of Neurology. Published continuously since 1951, it is now a weekly with 48 issues per year. Copyright (O 2019 American Academy of Neurology. All rights reserved. Print ISSN: 0028-3878. Online ISSN: 1526-632X.

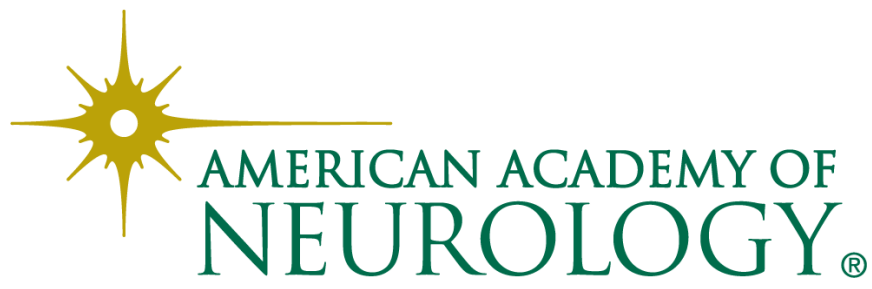

